\title{
India's Self, cross \& often cross pollinated crops in the global crop production: Mendelian variation perspectives
}

\author{
M. B. Dastagiri ${ }^{1}$, T. K Immanuelraj ${ }^{2}$, Ganeshagouda I. Patil ${ }^{3}$ \\ ${ }^{1}$ Principal Scientist, National Centre for Agricultural Economics and Policy Research, DPS Marg, Pusa, New Delhi, India \\ ${ }^{2}$ Scientist, National Centre for Agricultural Economics and Policy Research, DPS Marg, Pusa, New Delhi, India \\ ${ }^{3}$ Scientist, National Centre for Agricultural Economics and Policy Research, DPS Marg, Pusa, New Delhi, India \\ Email address: \\ dgiri_mb@yahoo.co.in(M. B. Dastagiri) \\ To cite this article: \\ M. B. Dastagiri, T. K Immanuelraj, Ganeshagouda I. Patil. India's Self, Cross \& Often Cross Pollinated Crops İn The Global Crop \\ Production: Mendelian variation Perspectives. Science Discovery. Vol. 1, No. 3, 2013, pp. 16-27. doi: 10.11648/j.sd.20130103.11
}

\begin{abstract}
Global agricultural growth has been slowing down. Crop production constitutes lion share of agricultural output. Empirical studies show that over the 40 years, crops growth rates in terms of yield gains and total production has been impressive but not substantial. This is mirroring in general in most of the developing countries and in India in particular. Crop plants originated from wild species through Mendelian variation, inter-specific hybridization or polyploidy. Genetic diversity plays an important role in crop improvement because hybridization between lines of diverse origin generally displays a greater heterosis than between, closely related strains. Infect, genetic diversity is more in cross-pollinated crops compared to self-pollinated crops. Until now, researchers and public are dealing with the agricultural production performance under cereals, pulses, oilseeds, fibber crops and so on but there is no (limited) study analyzed based on Mendelian variation. So this study uses new way of analyzes based on Mendelian variation perspective to study the production performance and growth trends of crops under self, cross and often cross-pollinated crops. The present paper is an attempt to examine critically the compound growth rates of area, production and productivity during distinct epochs in the agricultural development of India. Further, focus on the performance status of India's major crops vis-à-vis the top three crop productivity nations of the world with special reference to self, cross and often cross-pollinated crops for the period of 1950-51 to 2011-12. Essentially, such a comparison will provide insights regarding the magnitude of the yield-gap that countries having low productivity need to bridge. A comparison of India with other nations reveals that India is second in the rice, wheat and groundnut production. The production differences between India and those nations are substantial in cross and often cross-pollinated crops compare to self-pollinated crops. However, the productivity differences between India and high productivity countries are more in cross-pollinated crops followed by self and often cross-pollinated crops. India needs to explore comparative yield advantages in cross-pollinated crops. Rice and wheat are the two principal crops grown in India. Though cross pollinated and often cross pollinated crops such as maize, sugarcane, cotton and tobacco hold promise for the future, the incessant area expansion under rice and wheat have relegated these crops to the background. In India, compound growth rates reflect that the pivot of green revolution as wheat. This is reflected by the crop growth rate of $5.65 \%$ during green revolution period. All through wheat productivity increased at increasing rates of $1.27 \%, 2.67 \%$ and $2.97 \%$ indicates technological breakthroughs in wheat production. Similarly, cotton productivity also increased at increasing rates of $2.04 \%, 2.54 \%$, and $3.75 \%$. To conclude, among self-pollinated crops; India stands second in paddy, wheat, groundnut and first in jute production. But in terms of productivity India trails behind higher productive countries. This calls for steps to enhance productivity. Further, scientists should give more emphasis on cross-pollinated crops. Bureaus of plant genetic resources must preserve and take steps to enhance genetic diversity of these crops. Planners and policy makers must have vigilance in land allocation and price fixation based on Mendelian variation of crops.
\end{abstract}

Keywords: India, Globe, Self, Cross and Often Cross Pollinated Crops, Production Performance, Mendelian variation Approach 


\section{Introduction}

World agricultural growth has been slowing down (OECD-FAO, 2013). The growth rate fell from $3 \%$ in the 1960 's to $2.3 \%$ in 1970 's and $2 \%$ in 1980 's (WRI etal, 1996). Crop production which is by far the biggest component of agricultural output, has risen at an average annual rate of 2.6 per cent during the last 25 years compared to less than half a per cent per annum during the first half of the $20^{\text {th }}$ century. The average annual growth rate between 1880 and 1960 has been estimated and found that not more than 1.5 per cent in the U.S.A, 1.9 per cent in Japan, 1 percent in U.K. and 3 percent in Thailand, Mexico, and Malaysia (IFPRI, 1995). China, which is in size and diversity of natural conditions is close to India than any other country; the rate of growth in China in the last two decades may not have been higher than in India.

World Watch Institute (2004) reports that Increases in food production, per hectare of land, have not kept pace with increases in population, and the planet has virtually no more arable land or fresh water to spare. Throughout the history, yearly crop productivity gains have mostly been small about 2 to $15 \mathrm{~kg}$ per ha per annum. Gains of this order are too small to be of much benefit by themselves. But over the 40 years, the growth of agricultural growth in terms of yield gains and total production has been impressive and the yield gains achieved hold promise for making future gains (Dastagiri, 1998 and FAO, 2011). Since the early 1980 's world population growth continued unaborted due to which there was a gradual reduction in the availability of agricultural land per capita from 0.93 ha in the 1970 's which is projected to be 0.5 ha by 2000 (IFFRI, 1995). For countries that already have scarce land resources and high population, per capita agricultural land availability is estimated to be much lower 0.3 ha in the 1970's and 0.17 ha in the year 2000. In china, per capita land availability is projected to be as little as $0.1 \mathrm{ha}$ and while it would be 0.11 ha in India by 2000. Increasing scarcity of land and water resources, environmental degradation, and loss of biodiversity had begun to limit the expansion of food production in both developed and developing countries (Dastagiri etal 2013). Dastagiri and Immanuelraj (2012) found that shifting Indian farming from a rural lifestyle to an agribusiness sector and linking farmers to super markets is a key driver for industrialization.

The major interest of research workers so far was to assess whether crop production in India tended to increase or remained constant. In addition to the trends in crop production as whole, trends in land productivity i.e. yields per acre were studied. Researchers conclude that the productivity of crops is, though impressive, not substantial. In order to achieve higher productivity; crop scientists are developing input intensive, genetically improved and environmentally adaptive varieties. Crop plants originated from wild species through Mendelian variation, interspecific hybridization or polyploidy. In all these modes of evolution, natural and, perhaps, artificial selection played an important role. Plant breeding has been crucial in increasing agricultural production. Some well-known achievements are development of semi-dwarf wheat and rice varieties, mobilization of Indian canes, and production of hybrid and composites in maize, jowar and bajra (Singh, 1993). Genetic diversity plays an important role in plant breeding because hybridization between lines of diverse origin generally displays a greater heterosis than between, closely related strains. (V.V Singh, 2012) Infect, genetic diversity is more in cross-pollinated crops compared to self-pollinated crops. (ACIAR, 2010) The magnitude of heterosis increases with the genetic divergence in morphological traits and geographical origin of the parents. Heterosis is common in almost all the self-pollinated crops. But hybrid varieties are not used in most of them due to a greater difficulty in obtaining large quantities of the hybrid seed.

Infect, yields are depending on three major factors such as genetics, inputs and environment. All these are complimentary or supplementary in nature. Empirical studies show that the genetic variability is major source for developing HYV's because the other two; inputs and environment factors depend upon genetic responsiveness of crop. In general, genetic variation exists in cross-pollinated crops. On the basis of this plant breeders are improving crop productivity through crossing program. Until now, researchers and public are studying the crop production performance under cereals, pulses, oilseeds; fiber crops and so on but the studies based on variation were rare. So there is a need to study the trends of crops under self, cross and often cross-pollinated crops. The present paper is an attempt to assess the production status of India's major crops with the top three crop producing countries of the world with special reference to self, cross and often-cross pollinated crops and also to find out the variation in production among these crops besides identifying the future promising crops. It also reflects the future potential achievable in low productive countries on par with the other higher producing countries.

The specific objectives of the paper are

1. To estimate growth rates and trends of area, production and yield of self, cross and often cross pollinated crops during different periods in India and abroad.

2. To study and compare the performance of self, cross and often cross pollinated crops during different periods in India and abroad.

3. To find out future promising potential yielding crops to meet growing needs of population

4. To suggest suitable policies and strategies for resource allocation and development of self, cross and often cross pollinated crops in India and abroad. 


\section{Data and Methodology}

The study is based on new methodology of Mendelian variation approach. It is basically diagnostic study of Mendal variation in crops. Selected crops are classified based on Mendelian variation. The study uses time series data on selected crops like, self-pollinated (paddy, wheat, Groundnut and jute), cross pollinated (Maize and sugarcane) and often cross (cotton and tobacco) pollinated crops at India and Worlds level from the period of 1950-51 to 2011-12. Means, averages, ranks and compound growth were estimated. Graphical trend analysis also performed. The area, production and yield trends of these crops are estimated for three different periods viz; pre-green revolution, green revolution and post green revolution periods. The source referred for these above mentioned crops were Agricultural statistical at a glance-2012 (Department of Agriculture and co-operation, Ministry of Agriculture, Government of India) and FAO Stat (Food and Agriculture Organization) for India and world level respectively.

For analyzing the performance of self, cross and often cross pollinated crops during pre-green revolution (1950-51 to 1964-65), green revolution (1967-68 to 1980-81) and post-green revolution (1980-81 to 2010-11) and over all periods, the growth rate was employed in order to find out the differences/ changes over these periods. In the same way, in order to see the cropping pattern in India and also to arrive the selected self, cross and often pollinated crops scenario on production and yield differences of India in comparison with world and major producing countries, percentage share in contribution to the total world production and its rank etc. were analyzed using descriptive statistics like triennium average, percentages and summation etc. Finally, it suggests policies and strategies for scientists, planners and policy makers to adopt Mendelian variation in crop planning and improvement

\subsection{Growth Rate Formulae}

The compound growth rate (r) was calculated by fitting exponential function to the variables of interest viz., Area and Production for the period 1950-51 to 2010-11.

$$
Y_{t}=Y_{0}(1+r)^{t}
$$

Assuming multiplicative error term in the equation1, model may be linearized by logarithmic transformation

$$
\ln Y_{t}=A+B t+\varepsilon
$$

Where, $\mathrm{A}(=\ln \mathrm{A} 0)$ and $\mathrm{B}(=\ln (1+\mathrm{r}))$ are the parameters to be estimated by ordinary least square regression, $t=$ time trend in year, $r=\exp (B)-1$

\section{Results and Discussion}

Based on data available uniformly for all the countries the major principal crops are categorized in to three groups namely; self cross, often cross-pollinated crops shown in table1. Self-pollinated crops include; paddy, wheat, groundnut and jute. Cross-pollinated crops include; maize and sugarcane, whereas often cross-pollinated crops include commercial crops like cotton and tobacco.

Table 1. Crops distribution under self, cross and often cross-pollinated crops.

\begin{tabular}{cccc}
\hline $\begin{array}{c}\text { Sl. } \\
\text { No }\end{array}$ & $\begin{array}{c}\text { Self-pollinated } \\
\text { crops }\end{array}$ & $\begin{array}{c}\text { Cross pollinated } \\
\text { crops }\end{array}$ & $\begin{array}{c}\text { Often cross pollinated } \\
\text { crops }\end{array}$ \\
\hline 1 & Paddy & Maize & Cotton \\
2 & Wheat & Sugarcane & Tobacco \\
3 & Groundnut & - & - \\
4 & Jute & - & - \\
\hline
\end{tabular}

Source: Plant Breeding, B.D.Singh 50-55.

\begin{tabular}{|c|c|c|c|c|}
\hline \multirow{2}{*}{ Crop } & \multicolumn{2}{|c|}{ Area (million ha) } & \multicolumn{2}{|c|}{ Percentage share to gross cropped area } \\
\hline & 2008-09 & 2009-10 & 2008-09 & 2009-10 \\
\hline \multicolumn{5}{|c|}{ Self-pollinated crop } \\
\hline Paddy & 45.54 & 41.92 & 23.14 & 22.01 \\
\hline Wheat & 27.75 & 28.46 & 14.34 & 14.87 \\
\hline Groundnut & 6.16 & 5.48 & 3.19 & 2.14 \\
\hline Jute & 0.85 & 0.86 & 0.40 & 0.43 \\
\hline \multicolumn{5}{|c|}{ Cross pollinated crop } \\
\hline Maize & 8.17 & 8.26 & 4.16 & 4.29 \\
\hline Sugarcane & 4.42 & 4.17 & 2.50 & 2.59 \\
\hline \multicolumn{5}{|c|}{ Often cross pollinated crops } \\
\hline Cotton & 9.41 & 10.13 & 4.81 & 5.22 \\
\hline Tobacco & 0.39 & 0.44 & 0.23 & 0.19 \\
\hline
\end{tabular}

Table 2. Cropping pattern for all India (2009-10 and 2010-11)

Source: Agricultural statistics at a glance, 2012 


\subsection{India's Crop Production Performance}

India is one of the major crops producing country in the world. It has reputation in many spheres. Though it has tremendous potential in terms of productivity of crops, it is still unable to explore the expected targeted yields, due to biological and technological constraints. Cropping pattern adopted during 2008-10 is shown in table2. In self-pollinated crops, the area under gross cropped area in paddy cultivation was highest (22.01\%) followed by wheat $(14.87 \%)$, groundnut $(2.14 \%)$ and jute $(0.43 \%)$. In case of cross-pollinated crops, the maize and sugarcane occupied $4.29 \%$ and $2.59 \%$ gross cropped area. However, often cross-pollinated crops such as cotton occupied $5.22 \%$ and tobacco occupied only $0.19 \%$ of gross cropped area. The table clearly indicates that rice and wheat are the two principal crops grown under major arable land of India. Though cross, often cross-pollinated crops such as Sugarcane, cotton, and tobacco hold promise for the future, the incessant area expansion under rice and wheat have relegated these crops to the background.

\subsection{All India Compound Growth Rates of Area, Production and Productivity of Principal Crops}

India's crop production period from 1950-51 to 2010-11 divided into three technological breaks through periods. The all India compound growth rates of area, production and productivity of these periods were shown in table3. These growth rates critically examined during these distinct epochs of crop production development of India. The three technological breakthrough periods as follows.

i $\quad 1950-51$ to $1964-65 \quad--\quad$ Pre green revolution period

ii $\quad 1967-68$ to $1980-81 \quad$-- Green revolution period

iii 1980-81 to 2010-11 - Post green revolution period

\subsubsection{Self-Pollinated Crops}

\subsubsection{Paddy}

The area, production and productivity under paddy cultivation increased at a rate of $0.61 \%, 2.52 \%$ and $1.90 \%$ per annum respectively during $1950-51$ to $2010-11$. The growth in area under paddy was $1.45 \%, 0.75 \%, 0.30 \%$ during three periods indicating the diminishing allocation of land. Among the different periods the production growth rates were $4.35 \%, 2.18 \%$ and $2.40 \%$ respectively. During post green revolution period growth rate of $2.04 \%$ may be due to fertilizer and irrigation responsive HYV's. However, productivity growth rates among different periods were $2.86 \%, 1.42 \%$ and $1.73 \%$ respectively.

\subsubsection{Wheat}

The annual compound growth rate of wheat was $1.77 \%$ in area, $4.62 \%$ in production and $2.80 \%$ of productivity during 1950-51 to 2010-11. But the area allocation under different periods was $2.70 \%, 2.94 \%, 1.80 \%$. The production growth rates under different periods were $4.27 \%, 5.48 \%, 2.60 \%$. The remarkable growth rate of $5.48 \%$ during green revolution period symbolizing green revolution occurred in wheat crop. The per hectare yield compound growth rates among different periods were $1.53 \%, 2.45 \%, 1.78 \%$ shows that in all these periods the wheat productivity has been increasing.

\subsubsection{Groundnut}

Groundnut area, production and productivity are increasing at annual compound growth rates of $0.20 \%$, $1.11 \%$, and $0.91 \%$ during $1950-51$ to $2010-11$. Among different periods the production growth rates were $4.36 \%$, $0.64 \%, 0.92 \%$. The area under allocation of groundnut cultivation showing dwindling picture as their growth rates indicates $3.84 \%,-0.30 \%$, and $0.92 \%$ during different periods. Interestingly, during green revolution period the area under this crop decreased $-0.30 \%$ and later period also increased marginally of $0.92 \%$ indicates neglecting this important oilseed crop during these periods. However, for the same periods per hectare yields are increasing at increasing rate $(0.50 \%, 0.95 \%$, and $1.19 \%)$.

\subsubsection{Jute}

The area, production and productivity are increasing under jute cultivation at annual compound growth rates of $0.03 \%, 1.52 \%$, and $1.49 \%$ respectively during $1950-51$ to 2010-11. During different periods the area increased at the rate of $4.84 \%, 1.53 \%,-0.71 \%$ indicates drastic declining trend in land allocation under jute. Similarly, the production growth rates also showing declining trends $(5.45 \%, 2.59 \%$, and $1.31 \%$ ) during different periods. Contrastingly, the productivity growth rates showing increasing trend for the same periods $(0.59 \%, 0.04 \%$, and $2.04 \%)$.

\subsubsection{Cross Pollinated Crops}

\subsubsection{Maize}

During 1950-51 to 2010-11, the annual compound growth rates of area, production and productivity were $1.20 \%$, $3.15 \%$, and $1.93 \%$ respectively. Over the different periods the area under maize was increased at the rate of $2.68 \%$, $0.21 \%$, and $1.33 \%$. The mere increase in area at the rate of $0.21 \%, 0.33 \%$ during green revolution and post green revolution period indicates that the area expansion under maize cultivation is neglected. The production growth rates were $6.40 \%, 0.40 \%$, and $3.76 \%$. Whereas productivity increased at the rate of $3.62 \%$ and $2.40 \%$ during pre and post green revolution periods. 
Table 3. India compound growth rate of Area, Production and Yield of Principal crops

\begin{tabular}{|c|c|c|c|c|c|c|c|c|c|c|c|c|}
\hline \multirow[t]{2}{*}{ Crop } & \multicolumn{3}{|c|}{$1950-51$ to $2010-11$} & \multicolumn{3}{|c|}{$\begin{array}{c}\text { Pre green revolution period } \\
1950-51 \\
\text { to } 1964-65\end{array}$} & \multicolumn{3}{|c|}{$\begin{array}{c}\text { Green revolution period } \\
1967-68 \\
\text { to } 1980-81\end{array}$} & \multicolumn{3}{|c|}{$\begin{array}{c}\text { Post green revolution period } \\
1980-81 \\
\text { to } 2010-11\end{array}$} \\
\hline & $\mathbf{A}$ & $\mathbf{P}$ & $\mathbf{Y}$ & $\mathbf{A}$ & $\mathbf{P}$ & $\mathbf{Y}$ & $\mathbf{A}$ & $\mathbf{P}$ & $\mathbf{Y}$ & $\mathbf{A}$ & $\mathbf{P}$ & $\mathbf{Y}$ \\
\hline \multicolumn{13}{|c|}{ Self-pollinated crop } \\
\hline Paddy & 0.61 & 2.52 & 1.90 & 1.45 & 4.35 & 2.86 & 0.75 & 2.18 & 1.42 & 0.30 & 2.04 & 1.73 \\
\hline Wheat & 1.77 & 4.62 & 2.80 & 2.70 & 4.27 & 1.53 & 2.95 & 5.48 & 2.45 & 0.80 & 2.60 & 1.78 \\
\hline Groundnut & 0.20 & 1.11 & 0.91 & 3.84 & 4.36 & 0.50 & -0.30 & 0.64 & 0.95 & -0.92 & 0.27 & 1.19 \\
\hline Jute & 0.03 & 1.52 & 1.49 & 4.84 & 5.45 & 0.59 & 1.53 & 2.59 & 1.04 & -0.71 & 1.31 & 2.04 \\
\hline \multicolumn{13}{|c|}{ Cross pollinated crop } \\
\hline Maize & 1.20 & 3.15 & 1.93 & 2.68 & 6.40 & 3.62 & 0.21 & 0.40 & 0.19 & 1.33 & 3.76 & 2.40 \\
\hline Sugarcane & 1.69 & 3.04 & 1.33 & 3.19 & 6.36 & 3.07 & 1.65 & 2.64 & 0.98 & 1.68 & 2.27 & 0.59 \\
\hline \multicolumn{13}{|c|}{$\begin{array}{c}\text { Often cross pollinated } \\
\text { crops }\end{array}$} \\
\hline Cotton & 0.43 & 2.94 & 2.51 & 1.85 & 4.28 & 2.38 & 0.08 & 2.62 & 2.54 & 1.12 & 4.46 & 3.31 \\
\hline Tobacco & 0.01 & 1.49 & 1.47 & 1.75 & 3.07 & 1.32 & -0.08 & 2.19 & 2.30 & -0.40 & 0.62 & 0.97 \\
\hline
\end{tabular}

Source: Agricultural statistics at a glance, 2012, A = Area; $\mathrm{P}=$ Production; Y= Yield;

\subsubsection{Sugarcane}

The area, production and productivity under sugarcane increasing at annual compound growth rate of $1.69 \%, 3.04 \%$, and $1.33 \%$ respectively during $1950-51$ to $2010-11$. Under different periods the area growth rates were $3.19 \%, 1.65 \%$ and $1.68 \%$ respectively. The production is increasing under different periods at the rate of $6.36 \%, 2.64 \%, 2.27 \%$ per annum indicates impressive performance. The productivity of sugarcane during three periods increased at increasing rate.

\subsubsection{Often -Cross Pollinated Crops}

\subsubsection{Cotton}

During $1950-51$ to $2010-11$, the area, production and productivity under cotton increased at the rate of $0.43 \%$, $3.94 \%$, and $2.51 \%$ per annum. During different periods the area increased at the rate of $0.85 \%, 0.08 \%, 1.12 \%$ per annum indicates diminishing area allocation. The production of cotton during different periods is quiet impressive and growth rates were observed at the rate of $4.28 \%, 2.62 \%$, and $4.46 \%$ per annum. The productivity of cotton under different periods was $2.38 \%, 2.54 \%$ and $3.31 \%$ indicates productivity is increasing at increasing rate.

\subsubsection{Tobacco}

The trends in area, production and productivity under tobacco observed at the rate of $0.01 \%, 1.49 \%$, and $1.47 \%$ per annum during 1950-51 to 2010-11. Over the periods the area increased $1.75 \%$ during peregrine revolution period and negative growth of $-0.08 \%,-0.40 \%$ during green revolution and post green revolution period. This may be due to Government policy restriction on allocation of area under tobacco. The production growth rates during different periods were $3.07 \%, 2.19 \%$ and $0.62 \%$ indicates declining trend. The productivity growth rates during different periods were $1.32 \%, 2.30 \%$, and $0.97 \%$.

\subsection{Trends in Area and Productivity of Self, Often and Cross Pollinated Crops}

Trends in area and productivity of self-pollinated crops (Paddy, Wheat, Groundnut and Jute), cross pollinated crops (Maize and Sugarcane) and often cross-pollinated crops (Cotton and Tobacco) in India from the period of 1950-51 to 2010-11 have been depicted in the Figure 1, Figure 2 and Figure 3 respectively. This whole period (1950-51 to 2010-11) describes the trends in area and productivity performance of self, cross and often cross-pollinated crops during pre-green revolution, green revolution and post green revolutions periods. The self -pollinated crops like paddy, wheat and groundnut crops area as well as productivity trends had been increasing over the years especially during the green revolution. Whereas more increasing trends were observed in the cross pollinated crops like maize and sugarcane compare to self and often cross pollinated crops. While in the case of often cross pollinated crops like cotton and tobacco have reported negative trend in area and positive trend in productivity with some extent of fluctuations. 


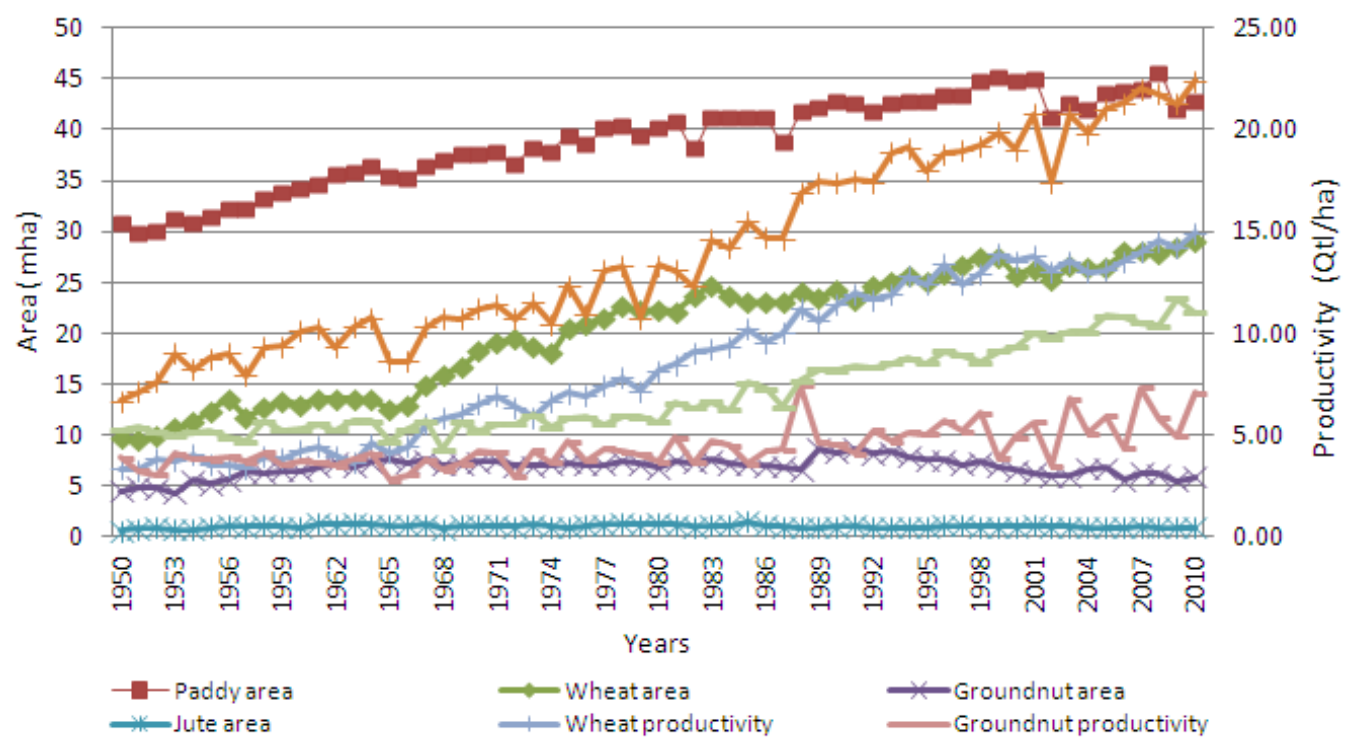

Fig 1. Trends of area and productivity of Self-Pollinatedcrop in India
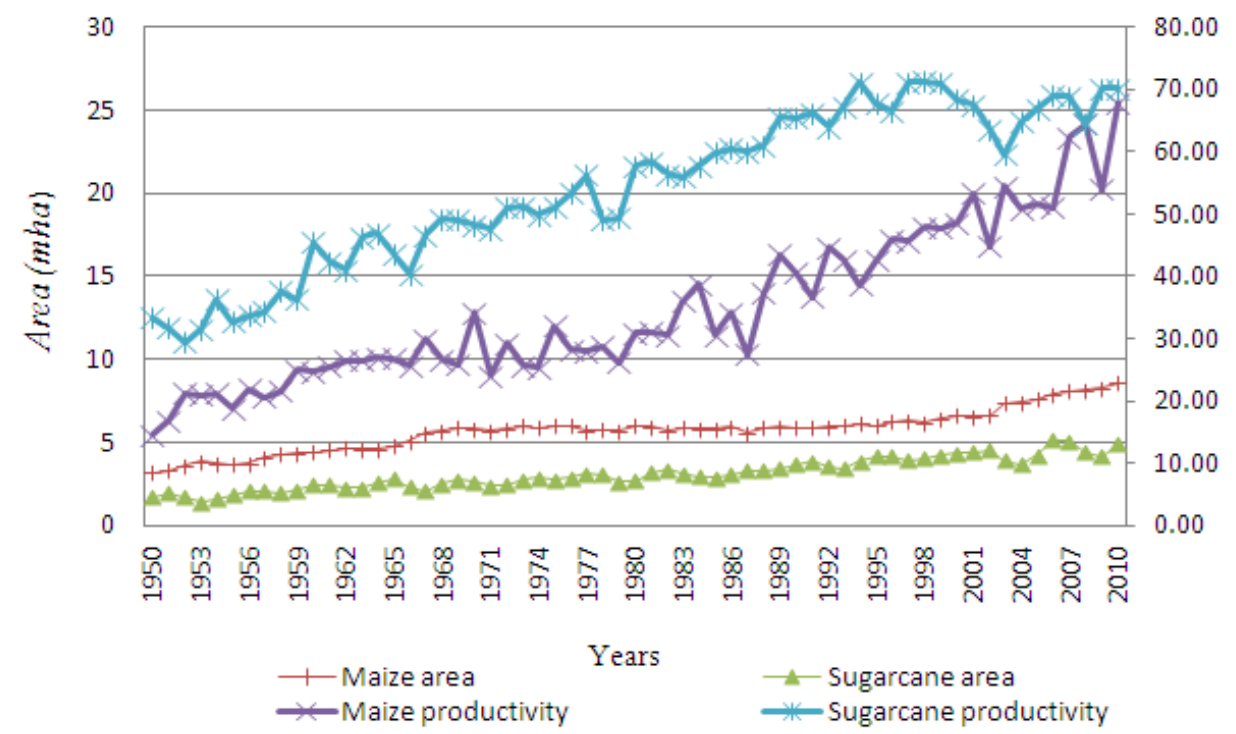

Fig 2. Trends of area and productivity of Cross pollinated crop in India

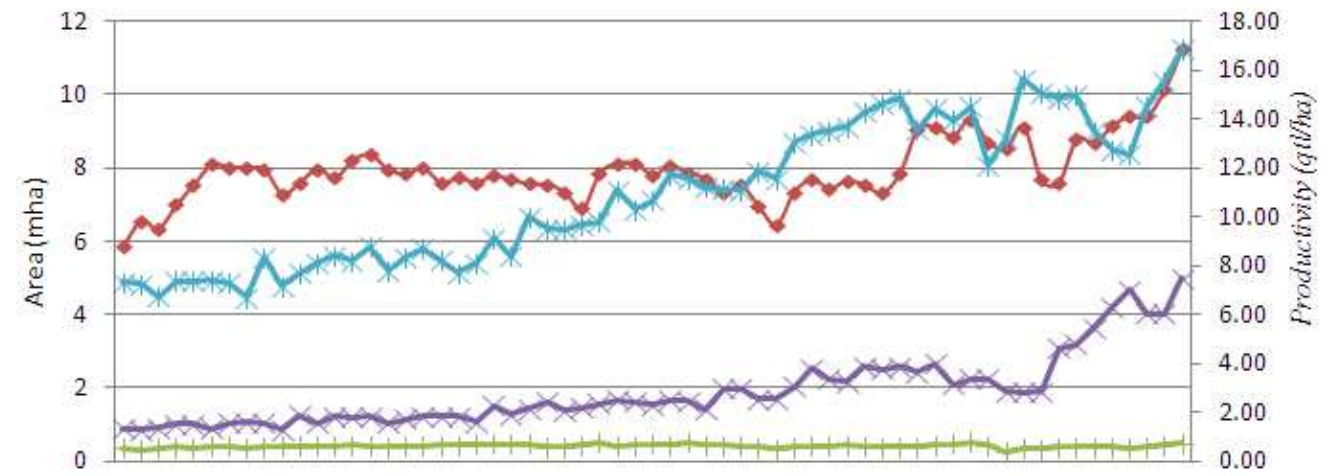

1355791113151719212325272931333537394143454749515355575961 Years

$\rightarrow$ Cottonarea $\longrightarrow$ Tobaccoarea $\quad$ Cotton productivity $\quad$ Tobacco productivity

Fig 3. Trends of area and productivity of Often Cross- pollinated crop in India 


\subsection{India and Top Producing Countries: Production Performance}

Production of major crops of India and top producing countries and their percentage shares in the world crop production are shown in tables 4-6. The triennium average (2009-12) world paddy production is 703 million tones, wheat $681.41 \mathrm{Mt}$, groundnut 39 million tons, jute $2.91 \mathrm{Mt}$, maize $851.48 \mathrm{Mt}$, sugarcane $1725.30 \mathrm{Mt}$, cotton $23.57 \mathrm{Mt}$ and 7.19 Mt for tobacco. All these values are well the average yields of highest producing countries of many developing countries.

\subsubsection{Self-Pollinated Crops}

\subsubsection{Paddy}

India ranked second in the world paddy production by producing $145.11 \mathrm{Mt}(20.64 \%)$. China topped in rice production in the world by recording $198.85 \mathrm{Mt}(28.29 \%)$. However, Indonesia took third position. The percentage of production gap between India and top producing country like china is about $7.64 \%$.

\subsubsection{Wheat}

Similarly, in wheat production also India stands second in the world by producing $82.79 \mathrm{Mt}$ (12.15\%). China topped in wheat production by producing $115 \mathrm{Mt}$, which constitutes $17.01 \%$ of world wheat production. The comparative statistics shows that India lag behind China in this regard by about $4.86 \%$.

\subsubsection{Groundnut}

China ranked first in the world groundnut production by producing $15.53 \mathrm{Mt}(39.83 \%)$ followed by India, which produced6.88 Mt (17.64\%). Nigeria stood third in position by accounting $3.25 \mathrm{Mt}(8.33 \%)$ of groundnut production. India is trailing behind China in this regard about $22.20 \%$.

\subsubsection{Jute}

India ranked first in world jute production with remarkable production of $1.69 \mathrm{Mt}(59.90 \%)$ followed by Bangladesh, which recorded 1.12 Mt. (38.58\%). However, China ranked third in jute production by producing $0.04 \mathrm{Mt}$ $(1.45 \%)$. The percentage production difference between India and Bangladesh/China is quite high indicating India's supremacy over other countries.

\subsubsection{Cross-Pollinated Crops}

\subsubsection{Maize}

India ranked sixth in world maize production by producing $20.01 \mathrm{Mt}(2.35 \%)$. U.S.A. topped in world maize production by accounting $320.88 \mathrm{Mt}(37.68 \%)$ followed by China 178.18 Mt (20.93\%) and Brazil 53.91 Mt. (6.33\%). India lags behind USA to a great extent (35.34\%) in production. This may be due to less area under cultivation or production/ technological constraints. Scientists need to concentrate on this crop because substantial scope in production improvement.

Table 4. Self-pollinated crops production and \% share of major producing countries of the would

\begin{tabular}{|c|c|c|c|c|}
\hline \multicolumn{4}{|c|}{ Triennium average 2009-12 } & \multirow{2}{*}{$\begin{array}{l}\text { \% difference between India and } \\
\text { the top producing countries in } \\
\text { yields }\end{array}$} \\
\hline Country & Production (million tones) & $\begin{array}{l}\% \text { share of the country } \\
\text { would production }\end{array}$ & Rank & \\
\hline \multicolumn{5}{|l|}{ Paddy } \\
\hline World & 702.99 & & & \multirow{6}{*}{7.64} \\
\hline India & 145.11 & 20.64 & Second & \\
\hline China & 198.85 & 28.29 & First & \\
\hline Indonesia & 65.54 & 9.32 & Third & \\
\hline Wheat & & & & \\
\hline World & 681.41 & & & \\
\hline India & 82.79 & 12.15 & Second & \multirow{3}{*}{4.86} \\
\hline China & 115.90 & 17.01 & First & \\
\hline USA & 58.28 & 8.55 & Third & \\
\hline \multicolumn{5}{|l|}{ Groundnut } \\
\hline World & 38.99 & & & \multirow{6}{*}{22.20} \\
\hline India & 6.88 & 17.64 & Second & \\
\hline China & 15.53 & 39.83 & First & \\
\hline Nigeria & 3.25 & 8.33 & Third & \\
\hline Jute & & & & \\
\hline World & 2.91 & & & \\
\hline India & 1.69 & 57.90 & First & \multirow{3}{*}{--} \\
\hline Bangladesh & 1.12 & 38.58 & Second & \\
\hline China & 0.04 & 1.45 & Third & \\
\hline
\end{tabular}

Source: FAO production year book, 2012

\subsubsection{Sugarcane}

Sugarcane production in India is recorded at $306.57 \mathrm{Mt}$, which constitute $17.77 \%$ of world sugarcane production.
Brazil topped in world sugarcane production by producing 214.36 Mt (41.40\%). However, China stood in third position by sharing $6.62 \%$ of world sugarcane production. 
India trailing lagging behind Brazil by 6.62 percent in the sugarcane production.

\subsubsection{Often-Cross Pollinated Crops}

\subsubsection{Cotton}

Historically, cotton is an important crop in India. India ranked second in world cotton production by producing 5.25 Mt. (22.27\%). China topped in world cotton production by recording 6.31 Mt. (26.71\%). However, USA stood in third with production of $3.34 \mathrm{Mt}(14.15 \%)$. Though India is famous for cotton production since ancient times the production difference between China and India is about $4.50 \%$.

\subsubsection{Tobacco}

Similarly, in tobacco production also India ranked third in the world by producing $0.79 \mathrm{Mt}$ which accounts $11.03 \%$. China topped in world tobacco production by producing 3.08 Mt. (42.81\%) tobacco. However, U.S.A. stood second with record production of $0.87 \mathrm{Mt}$. (12.07\%). The production difference between first and third position countries is about $31.78 \%$ of production.

From the above scenario, We can infer that India need to keep attention on maize production and China on sugarcane production. In general, china and India occupied first or second ranks in most of the crop production due to more area under cultivation. However, India is unable to explore yield potential of cross and often cross-pollinated crops except in sugarcane where substantial production is possible.

Table 5 Cross-pollinated crops production and \% share of major producing countries of the world

\begin{tabular}{|c|c|c|c|c|}
\hline \multicolumn{4}{|c|}{ Triennium average $2009-12$} & \multirow{2}{*}{$\begin{array}{c}\% \text { difference between India and } \\
\text { the top producing countries in } \\
\text { yields }\end{array}$} \\
\hline Country & Production (million tones) & $\begin{array}{l}\% \text { share of the country } \\
\text { would production }\end{array}$ & Rank & \\
\hline \multicolumn{5}{|l|}{ Maize } \\
\hline World & 851.48 & & & \\
\hline India & 20.01 & 2.35 & & 35.34 \\
\hline UAS & 320.88 & 37.68 & First & \\
\hline China & 178.18 & 20.93 & Second & \\
\hline Brazil & 53.91 & 6.33 & Third & \\
\hline \multicolumn{5}{|l|}{ Sugarcane } \\
\hline World & 1725.30 & & & \\
\hline India & 306.57 & 17.77 & Second & 23.64 \\
\hline Brazil & 714.36 & 41.40 & First & \\
\hline China & 114.29 & 6.62 & Third & \\
\hline
\end{tabular}

Source: FAO production year book, 2012

Table 6. often cross-pollinated crops production and \% share of major producing countries of the world

\begin{tabular}{|c|c|c|c|c|}
\hline \multicolumn{4}{|c|}{ Triennium average 2009-12 } & \multirow{2}{*}{$\begin{array}{l}\text { \% difference between India and } \\
\text { the top producing countries in } \\
\text { yields }\end{array}$} \\
\hline Country & $\begin{array}{c}\text { Production } \\
\text { (million tones) }\end{array}$ & $\begin{array}{l}\% \text { share of the country } \\
\text { would production }\end{array}$ & Rank & \\
\hline \multicolumn{5}{|l|}{ Cotton } \\
\hline World & 23.57 & & & \\
\hline India & 5.25 & 22.27 & Second & 4.50 \\
\hline China & 6.31 & 26.77 & First & \\
\hline USA & 3.34 & 14.15 & Third & \\
\hline \multicolumn{5}{|l|}{ Tobacco } \\
\hline World & 7.19 & & & \\
\hline India & 0.79 & 11.03 & Third & 31.78 \\
\hline China & 3.08 & 42.81 & First & \\
\hline Brazil & 0.87 & 12.07 & Second & \\
\hline
\end{tabular}

Source: FAO production year book, 2012

\subsection{Area \& Yield per Hectare Status of Principal Crops in the World}

The area, per hectare yield, rank with respect to yield and yield difference between India and top producing countries in respective crops are shown in Tables 7 to 9. In 2011-12 -
World per hectare yield was 4.40 tones/ha in paddy, wheat $3.11 \mathrm{t} / \mathrm{ha}$, ground nut $1.68 \mathrm{t} / \mathrm{ha}$, jute $2.19 \mathrm{t} / \mathrm{ha}$, maize 5.18 $\mathrm{t} / \mathrm{ha}$, sugarcane $70.54 \mathrm{t} / \mathrm{ha}$, cotton $743 \mathrm{~kg}$ lint $/$ ha and 1.78 $\mathrm{t} / \mathrm{ha}$ tobacco. All these values are well above the per hectare yields of highest producing developing countries and yet are far below theoretical yields. Scope for yield 
improvement in most of these crops exists in many developing countries.

\subsubsection{Self-Pollinated Crops}

\subsubsection{Paddy}

India ranked forty-seventh in world rice productivity by producing 3.53t/ha. Egypt stood first by producing $9.56 \mathrm{t} / \mathrm{ha}$ followed by Australia (9.54 t/ha) and Turkey (9.05t/ha). In production, China and India ranked first and second respectively because area under rice is substantially high in these countries. India is allocating substantially $26.86 \%$ (44.10 million hectares) area under rice and producing $20.64 \%$ production. Whereas, the countries like, Egypt, Australia and Turkey are allocating marginal land for rice production even though these are better position in productivity. The productivity difference between India and top producing country like Egypt is remarkably high about $6.03 \mathrm{t} / \mathrm{ha}$. India can explore the productivity difference by producing high yielding fertilizer and irrigation responsive varieties or by producing better ide types and genotypes.

Table 7. Self-pollinated crop Area, yield per hectare of principal crops in major producing countries of the world-2011-12

\begin{tabular}{|c|c|c|c|c|}
\hline Country & $\begin{array}{c}\text { Area } \\
\text { (million ha) }\end{array}$ & $\begin{array}{c}\text { Yield } \\
\text { tones/ha }\end{array}$ & $\begin{array}{c}\text { Rank with respect to } \\
\text { yield }\end{array}$ & $\begin{array}{l}\text { Yield difference between India } \\
\text { and top producing country }\end{array}$ \\
\hline \multicolumn{5}{|l|}{ Paddy } \\
\hline World & 164.12 & 4.40 & & \\
\hline India & $44.10(26.86)$ & 3.53 & Fifty-seven & 6.03 \\
\hline Egypt & $0.59(0.36)$ & 9.56 & First & \\
\hline Australia & $0.08(0.04)$ & 9.54 & Second & \\
\hline Turkey & $0.10(0.06)$ & 9.05 & Third & \\
\hline \multicolumn{5}{|l|}{ Wheat } \\
\hline World & 220.39 & 3.11 & & \\
\hline India & $29.05(13.19)$ & 2.99 & Fifty-four & 6.87 \\
\hline Ireland & $0.09(0.04)$ & 9.86 & First & \\
\hline Belgium & $0.20(0.09)$ & 8.40 & Second & \\
\hline Netherlands & $0.15(0.07)$ & 7.78 & Third & \\
\hline \multicolumn{5}{|l|}{ Groundnut } \\
\hline World & 21.77 & 1.68 & & \\
\hline India & $4.19(19.24)$ & 1.65 & Thirty-five & 11.40 \\
\hline Cyprus & 0.00002 & 13.05 & First & \\
\hline Israel & $0.002(0.008)$ & 7.22 & Second & \\
\hline Nicaragua & $0.04(0.18)$ & 4.58 & Third & \\
\hline \multicolumn{5}{|l|}{ Jute } \\
\hline World & 1.37 & 2.19 & & \\
\hline India & 0.61 & 2.00 & Sixth & 8.55 \\
\hline Uzbekistan & 0.001 & 10.55 & First & \\
\hline Bhutan & 0.0001 & 3.97 & Second & \\
\hline Viet Nam & 0.004 & 3.50 & Third & \\
\hline
\end{tabular}

Source: FAO production year book, 2012

\subsubsection{Wheat}

India ranked forty-four in world wheat productivity by recording $2.99 \mathrm{t} / \mathrm{ha}$. Ireland topped in wheat productivity by producing $9.86 \mathrm{t} / \mathrm{ha}$. However, by producing $8.40 \mathrm{t} / \mathrm{ha}$ and $7.78 \mathrm{t} /$ ha Belgium and Netherlands occupies second and third position respectively. The productivity difference between India and first producing country is around 6.87 $\mathrm{t} / \mathrm{ha}$. India need to increase the differential productivity by producing input responsive H.Y.V's and better genotypes. India is allocating highest area about 29.01 million hectares $(13.19 \%)$ area under wheat in the world. The top three producing countries are allocating less land under wheat cultivation but recorded more productivity.

\subsubsection{Groundnut}

By producing $1.65 \mathrm{t} / \mathrm{ha}$, India ranked thirty-five in groundnut productivity in the world. Cyprus ranked first by producing $13.05 \mathrm{t} / \mathrm{ha}$ followed by Israel (7.22 t/ha) and Nicaragua (4.58 t/ha). India is allocating $4.19 \mathrm{~m} . \mathrm{ha}$ (19.24\%) land under groundnut whereas the counties like Cyprus, Israel and Nicaragua are allocating less land under groundnut cultivation but recorded more productivity. This indicates these countries are using land judiciously and 
producing better. The productivity difference between India and Cyprus is about 11.40 tons per ha.

\subsubsection{Cross Pollinated Crops}

\subsubsection{Maize}

India ranked Eighty-one in maize productivity by recording yield of $2.97 \mathrm{t} / \mathrm{ha}$. Israel ranked first by producing $33.82 \mathrm{t} / \mathrm{ha}$ followed by Jordan (20.68 t/ha) and Kuwait $(20.17 \mathrm{t} / \mathrm{ha})$. USA is allocating the lion share of $33.98 \mathrm{~m}$.ha $(19.94 \%)$ of land under maize cultivation followed by China (33.56\%) and Brazil (7.75\%). The per hectare yield difference between India and Israel is remarkably high about $30.85 \mathrm{t} / \mathrm{ha}$.

\subsubsection{Sugarcane}

By recording yield of $69.25 \mathrm{t} / \mathrm{ha}$, India ranked thirty-six positions in sugarcane productivity. Ethiopia ranked first by producing $126.93 \mathrm{t} /$ ha followed by Peru (123.46 t/ha), and Colombia (119.62 t/ha). India is allocating $4.94 \mathrm{~m} . \mathrm{ha}$ $(19.43 \%)$ of land under sugarcane production. The highest land allocating country is Brazil (37.74\%). per hectare yield gap between India and Egypt is $57.48 \mathrm{t} / \mathrm{ha}$.

Table 8. Cross pollinated crop Area, yield per hectare of principal crops in major producing countries of the world-2011-12

\begin{tabular}{ccccc}
\hline Country & $\begin{array}{c}\text { Area } \\
\text { (million ha) }\end{array}$ & $\begin{array}{c}\text { Yield } \\
\text { tones/ha }\end{array}$ & $\begin{array}{c}\text { Rank with } \\
\text { respect to yield }\end{array}$ & $\begin{array}{c}\text { Yield difference between } \\
\text { India and top producing } \\
\text { country }\end{array}$ \\
\hline Maize & 170.40 & 5.18 & & \\
World & 7.27 & 2.97 & Eighty-one & 30.85 \\
India & 0.003 & 33.82 & First & Second \\
Israel & 0.001 & 20.68 & Third & \\
Jordan & 0.001 & 20.17 & \\
Kuwait & & & Thirty-six \\
Sugarcane & 25.43 & 70.54 & First \\
World & 4.94 & 69.25 & Second \\
India & 0.02 & 126.93 & Third \\
Ethiopia & 0.08 & 123.46 & 119.62 & 57.68 \\
Peru & 0.19 & & \\
Colombia & &
\end{tabular}

Source: FAO production year book, 2012

\subsubsection{Often-Cross Pollinated Crops}

\subsubsection{Cotton}

India ranked sixteenth in cotton productivity by producing $501 \mathrm{Kg}$ lint/ha. Australia occupied first position by recording $1909 \mathrm{Kg}$ lint/ha, followed by Israel $(1676 \mathrm{Kg}$ lint/ha), Brazil (1334 Kg lint/ha). India is allocating 9.5 m.ha areas under cotton whereas the countries like Australia, Israel, Brazil are allocated less land under cotton cultivation even though they were found to be better in yield. The productivity difference between India and Australia is about $1175 \mathrm{Kg}$ lint/ha.

\subsubsection{Tobacco}

By producing yield of $1.89 \mathrm{t} / \mathrm{ha}$, India ranked forty-eight in tobacco productivity. United Arab Emirates (UAE) recorded top in tobacco productivity by producing 21.30 t/ha followed by Peru $14.21 \mathrm{t} / \mathrm{ha}$ and Oman (4.88 t/ha). India is allocating $0.53 \mathrm{~m}$.ha area for tobacco cultivation. Top producing countries are allocating less land under tobacco cultivation. Yield gap between India and UAE is about $19.41 \mathrm{t} / \mathrm{ha}$. Though India is allocating sizeable land under self-pollinated crops like rice $(26.86 \%)$, wheat $(13.19 \%)$ and groundnut $(19.14 \%)$ and Jute $(45.20 \%)$ but its productivity rank in the world is forty-seven, forty-four and thirty-five and sixth respectively. The productivity differences between India and top producing countries are in rice 6.03 tones, wheat 6.87 tones, groundnut 11.40 tones and Jute 8.55 tones indicates that India need to explore comparative yield advantage in these crops.

In case of cross-pollinated crops like maize and sugarcane, India is allocating $4.26 \%, 19.45 \%$ land respectively. But their productivity ranks were Eighty-one and thirty-six respectively. The productivity differences between India and top producing countries are in maize $30.85 \mathrm{t} / \mathrm{ha}$ and in sugarcane $57.68 \mathrm{t} / \mathrm{ha}$. Whereas for often cross-pollinated crops like cotton and tobacco India is allocating land of $26.65 \%, 12.54 \%$ respectively and ranked sixteenth and forty-eight respectively. The productivity differences between India and top producing countries are in cotton $1175 \mathrm{Kg}$ lint/ha and in tobacco $19.41 \mathrm{t} / \mathrm{ha}$ respectively. 
Table 9. often cross -pollinated crop Area, yield per hectare of principal crops in major producing countries of the world - 2011-12

\begin{tabular}{ccccc}
\hline Country & $\begin{array}{c}\text { Area } \\
\text { (million ha) }\end{array}$ & Yield & $\begin{array}{c}\text { Rank with respect to } \\
\text { yield }\end{array}$ & $\begin{array}{c}\text { Yield difference between India } \\
\text { and top producing country }\end{array}$ \\
\hline Cotton & 34.11 & $($ Kg lint per ha $)$ & \\
World & 9.15 & 743 & Sixteen \\
India & 0.14 & 501 & First & 1175 \\
Australia & 0.013 & 1909 & Second & Third \\
Israel & 1.07 & 1676 & \\
Brazil & 1334 & Forty-eight \\
Tobacco & 4.25 & $($ tones/ha) & First \\
World & 0.53 & 1.78 & Second \\
India & 0.00004 & 1.89 & Third \\
United Arab Emirates & 0.001 & 21.30 & 14.21 & 19.41 \\
Peru & 0.0002 & 4.88 & \\
Oman & & &
\end{tabular}

Source: FAO production year book, 2012

\section{Conclusions}

Crop production performance needs to be evaluated based on Mendelian variation. Rice and Wheat are the two principal crops grown under major arable land of India. Though cross and often cross pollinated crops such as maize, sugarcane, cotton, and tobacco are the promising crops of the future, the area under these crops is not expanding because farmers are giving more importance to food grains crops like rice and wheat.

Crop production under different technological breakthrough periods namely; pre green revolution, green revolution and post green revolution periods reveals that during green revolution period higher paddy production growth of $2.18 \%$ is impressive may be due to higher yield obtained because of fertilizer and irrigation responsive of HYV's. The remarkable wheat growth rate of $5.48 \%$ during green revolution period symbolizing green revolution occurred in wheat crop. During different periods the wheat productivity increased at the rate of $1.53 \%, 2.45 \%, 1.78 \%$ indicates technological breakthrough happened in wheat production in India. Interestingly, during green revolution period the area under groundnut is decreased at the rate of $-0.30 \%$ per annum and later period also decreased marginally $-0.92 \%$ indicates neglecting this important oilseed crop during these periods. The mere increase in area of $0.21 \%, 1.33 \%$ under maize during green revolution and post green revolution period indicates the area expansion under maize is neglected during these periods. During different periods the cotton productivity increased at the rate of $2.38 \%, 2.54 \%$ and $3.31 \%$ indicates technological breakthrough happened in cotton production in India. The declining allocation of area under tobacco cultivation may be due to government restriction.

The triennium averages (2009-12) world production of paddy (702.99 Mt), wheat (681.41 Mt), groundnut (38.99 $\mathrm{Mt})$, jute (2.91 Mt), maize (851.48 Mt), sugarcane (1725.30 $\mathrm{Mt})$, cotton $(23.57 \mathrm{Mt})$ and tobacco $(7.19 \mathrm{Mt})$ are well above the average yields of highest producing countries of many developing countries.

The India and top countries crops producing scenario of self-pollinated crops reveals; china ranked first and India is second in the world in rice, wheat and groundnut production. The production gap between India and china in rice is about $7.64 \%$, in wheat and groundnut is about $4.86 \%$ and $522.20 \%$ respectively. However, India ranked top in jute production. In case of cross-pollinated crops; U.S.A. ranked first in the world maize production with record production of $320.88 \mathrm{Mt}$. (37.68\%). India trails behind U.S.A a greater extent $(35.34 \%)$ of maize production. Whereas in case of sugarcane production, Brazil ranked first in the world by producing $714.36 \mathrm{mt}$ (41.40\%). India lags behind Brazil in sugarcane production. Whereas in often-cross pollinated crops; China ranked first in the world in both cotton and tobacco production by recording $6.31 \mathrm{Mt}$. (26.77\%) of cotton and $3.08 \mathrm{Mt}$. (42.81\%) tobacco. The production difference between china and India is substantial about $4.50 \%$ in cotton and $31.78 \%$ in tobacco.

The world per hectare yield of crops in 2011-12 shows that - in self-pollinated crops; paddy per hectare yield is 4.40 tones/ha, wheat $3.11 \mathrm{t} / \mathrm{ha}$, and groundnut $1.68 \mathrm{t} / \mathrm{ha}$ and 
jute $2.19 \mathrm{t} / \mathrm{ha}$. In case of cross-pollinated crops; the productivity of maize is $5.18 \mathrm{t} / \mathrm{ha}$ and sugarcane $70.58 \mathrm{t} / \mathrm{ha}$. Further, in often cross-pollinated; per hectare yield of cotton is $743 \mathrm{~kg}$ lint/ha and tobacco is $1.78 \mathrm{t} / \mathrm{ha}$. All these values are well above the per hectare yields of highest producing countries of many developing countries and yet far below theoretical yields. There is clearly room for yield improvement in most of the crops and regions.

The India and major countries productivity scenario of self-pollinated crops reveals that Egypt stood first in paddy, Ireland in wheat, Cyprus in groundnut and Uzbekistan in jute. The productivity differences between India and top producing countries are in paddy $6.03 \mathrm{t} / \mathrm{ha}$, in wheat 6.87 $\mathrm{t} / \mathrm{ha}$, in groundnut $11.40 \mathrm{t} / \mathrm{ha}$ and in jute $8.55 \mathrm{t} / \mathrm{ha}$. Whereas in cross-pollinated crops; Israel ranked first in maize, Ethiopia in sugarcane. The productivity differences between India and top producing are $30.85 \mathrm{t} / \mathrm{ha}$ in maize and $57.68 \mathrm{t} / \mathrm{ha}$ in sugarcane. In case of often cross-pollinated crops; Australia ranked first in cotton and UAE in tobacco. The productivity differences between India and top producing countries are $1175 \mathrm{~kg}$ lint/ha in cotton and $19.41 \mathrm{t} / \mathrm{ha}$ in tobacco. India needs to explore comparative yield advantage in these crops.

India is allocating sizeable land under self-pollinated crops like rice $(26.86 \%)$, wheat $(13.19 \%)$ and groundnut $(19.14 \%)$ but its productivity rank in the world is forty-seventh, forty-four and thirty-five respectively. In case of cross-pollinated crops like maize and sugarcane, India is allocating $4.26 \%$ and $19.43 \%$ land respectively. But their productivity ranks were eighty-one and thirty-six respectively. Whereas for often - cross-pollinated crops like cotton and tobacco India is allocating $26.82 \%, 12.54 \%$ land respectively and ranked sixteenth and forty-eight respectively.

To conclude, the top two producing countries of the world; China and India ranked first or second in production of almost all the crops because of the more area under cultivation. But in case of productivity they are trailing behind high producing countries a greater extent indicates these countries need to take necessary steps to enhance productivity. Further, in India scientists should keep attention in developing better ideotypes, genotypes, crop diversification in self-pollinated crops and application of high-tech agricultural tools like crop modeling, computer simulation models, Biotechnology, genetic engineering and nanotechnology concepts to explore genetic diversity in cross and often-cross pollinated crops. Bureaus of plant genetic resource must preserve and take necessary steps to enhance genetic diversity. The planners and policy makers must have vigilance in land allocation and price fixation based on Mendelian variation approach. Scientists should have strategies in Research \& Development of crops based on Mendelian variation approach.

\section{References}

[1] ACIAR, (2010), Plants in Action, Australian Society of Plant Scientists, published by New Zealand Society of Plant Biologists, and New Zealand Institute of Agricultural and Horticultural Science, Australia

[2] Dastagiri M.B., 'World Food Production Research' Out Look on Agriculture, Vol. 27(2), June 1998, pp. 77-80.

[3] Dastagiri M.B and Immanuelraj T.K (2012) Supermarket Supply Chains in Horticulture in India: The Novel Marketing Models, Effects and Policies. Agrotechnology 1:107, doi10417/2168-9881

[4] Dastagiri M.B. et. al. (2013), Indian Vegetables: Production Trends, Marketing Efficiency and Export Competitiveness". American Journal of Agriculture and Forestry, Science PG, USA, 1(1):1-11.

[5] FAO, (2012) 'Production Yearbook, FAO of the United Nations, Rome, Italy.

[6] Govt. of India, 2012 'Area, Production \& Yield of major crops in different countries, Agricultural Statistics at a Glance, Directorate of Economics and Statistics, pp.55-63.

[7] IFPRI (1995), "population and food in the early twenty-first century: meeting future food demand of an increasing population, IFPRI 2020 Vision, Washington, D.C.OECD, FAO Agricultural Outlook, 2012-2021

[8] Singh B. D.( 1993), 'Modes of Reproduction and Pollination Control' Plant Breeding, Kalyani Publishers. New Delhi.

[9] Singh, V. V, Rai, P. K, Siddiqui, S. A. Verma V. and and Rajbir Yadav (2011), Genetic variability and relative drought tolerance in interspecific progenies of Brassica juncea. Agriculture and biology journal of North America, doi: 10.5251

[10] World Watch Institute (2004) World Watch Magazine. September/ October 2004, 17(5).

[11] WRI, UNEP, UNDP, WB (1996), World Resources: A guide to the global environment 1996-1997, Oxford University Press, Washington. 